
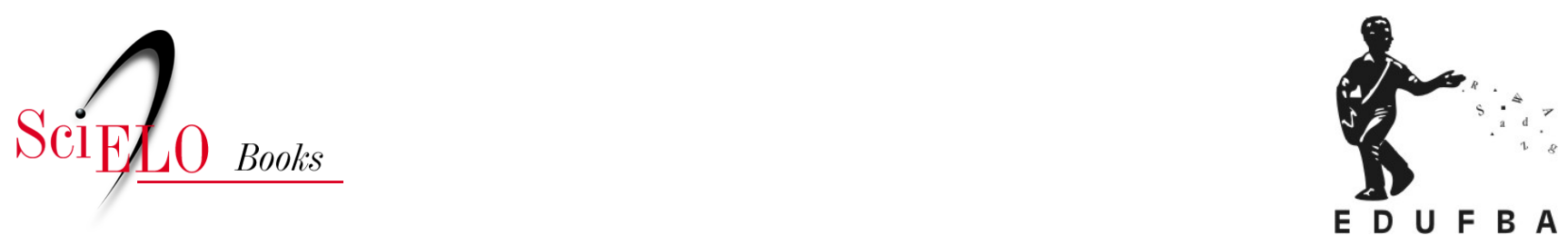

\title{
Prefácio da primeira edição de A construção da igualdade
}

\author{
Peter Fry
}

\section{SciELO Books / SciELO Livros / SciELO Libros}

FRY, P. Prefácio da primeira edição de A construção da igualdade. In: MACRAE, E. A construção da igualdade-política e identidade homossexual no Brasil da "abertura" [online]. Salvador: EDUFBA, 2018, pp. 9-13. ISBN 978-85-232-1998-7. https://doi.org/10.7476/9788523219987.0001.

All the contents of this work, except where otherwise noted, is licensed under a Creative Commons Attribution 4.0 International license.

Todo o conteúdo deste trabalho, exceto quando houver ressalva, é publicado sob a licença Creative Commons Atribição 4.0. 


\section{Prefácio da primeira edição de A construção da igualdade}

A beleza está no olhar de quem vê. Da mesma forma, os textos perdem sua objetividade para o olhar histórico de quem os lê. Assim, as etnografias, tantas vezes escritas no "presente etnográfico", serão sempre textos históricos, cujo significado será dado pela perspectiva social, cultural e historicamente distante dos seus leitores.

A leitura deste livro, que trata de eventos que ocorreram há menos de uma década atrás, provoca intensa emoção e uma nostalgia até dolorosa. $\mathrm{O}$ apagar das luzes da ditadura militar coincidia com um otimismo cultural e social bastante generalizado, e os rapazes e moças que fizeram acontecer o movimento homossexual sonhavam com uma sociedade mais justa e igualitária e, sobretudo, uma sociedade em que sua homossexualidade, liberta de todos os tabus, poderia ser celebrada sem restrição. Agora, os tempos são radicalmente outros: vivemos uma conjuntura política e econômica que frustra a todos, e a libertação da homossexualidade está sediada por um vírus misterioso e mortífero.

A história é contada admirável e detalhadamente por Edward MacRae, que, nas melhores tradições da antropologia, se dedicou a combinar os papéis de observador e participante, narrando e vivenciando 
os eventos que descreve e analisa. Com simpatia para com seus amigos e o máximo de objetividade - um ideal, por definição, nunca realizado mas, mesmo assim, guia indispensável para qualquer trabalho sociológico honesto -, Edward MacRae relata os triunfos e desapontamentos, as felicidades e tristezas, e os momentos de união eufórica e cisão amarga do movimento homossexual brasileiro.

Como muitos movimentos de libertação, o movimento homossexual brasileiro esposou um ideal antiautoritário, pressupondo a igualdade de todos seus membros. Este mesmo ideal supõe também uma semelhança fundamental e como que essencial entre os militantes. Na sua análise do nascimento, organização, cisão e relativo desfalecimento do movimento, MacRae mostra como esse ideal esbarrava constantemente contra outros menos explícitos. Os militantes não eram tão iguais assim: uns falavam melhor do que outros, assim dominando as reuniões e influindo mais na tomada de decisão. As mulheres e os negros homossexuais logo se sentiram suficientemente diferentes para formar seus próprios grupos, buscando escapar do machismo e racismo dos outros para poder melhor "trabalhar suas condições específicas". Havia também uma intensa disputa entre aqueles ligados aos partidos políticos e aqueles que acreditavam na necessidade de manter, a todo custo, a autonomia do movimento homossexual. Esta última tensão, especificamente centrada em acusações contra manobras escusas da Convergência Socialista, levou a uma grande e irreparável cisão - o "racha" - no grupo originário do Somos - SP.

Embora centrado no movimento homossexual, o livro tece constantes comparações com outros movimentos sociais da época, sobretudo o movimento feminista, cujas ideias e práticas em muito inspiraram os jovens militantes homossexuais. Assim, creio que o trabalho de Edward MacRae será leitura essencial para todos aqueles que procuram entender melhor o crescimento dos movimentos sociais brasileiros no passado recente e, por conseguinte, sua fase atual.

Uma das coisas que mais me chamou atenção ao ler de novo este livro - fiz parte da banca que examinou uma versão anterior que foi a tese de doutorado do autor - foi uma defasagem bastante grande entre as expectativas dos membros do movimento e a realidade da 
reação pública às reivindicações libertárias. As comemorações do dia primeiro de maio de 1980, programadas pelos metalúrgicos grevistas de São Bernardo do Campo, suscitaram acalorados debates entre os militantes paulistas. Finalmente, uma parte do Somos - aquela que adotava uma posição menos radicalmente autonomista do movimento homossexual - resolveu participar do evento, mas não sem bastante trepidação. Afinal, os sindicatos eram vistos como epicentro do machismo e bastião dos defensores da "luta maior" que privilegiavam a luta de classe e acusavam todos os demais movimentos de serem "diversionistas". Para espanto de todos, porém, os militantes homossexuais foram recebidos com aplausos entusiastas pelos operários. Numa outra ocasião, o pessoal do Somos participou de uma passeata pelo centro de São Paulo, em protesto contra a ação da polícia que perseguia prostitutas e pessoas acusadas de serem homossexuais. Mais uma vez a apreensão. Mais uma vez a ovação. O único caso citado de reprovação concreta foi o de um grampeador lançado da janela de um prédio na rota da passeata.

Com muita razão, o autor considera essa falta de repressão visível ou legal - o Brasil é um caso raro por nunca ter tido nenhuma legislação homofóbica - um dos grandes entraves à organização e à disseminação do movimento homossexual no Brasil. Afinal, nos Estados Unidos havia leis draconianas - ainda há em alguns estados - contra a homossexualidade e, lá, o movimento homossexual teve que enfrentar uma oposição forte e violência. Haja visto o famoso Stonewall Riot, em 1969. Na ausência de um inimigo identificável e tangível, o movimento teve que "inventá-lo", seja ele na Convergência Socialista e nos outros partidos de esquerda - os defensores de "luta maior" -, seja ele dentro do próprio movimento. Correlatas são as cisões e disputas pelo minipoder que o movimento gera. Correlata também - creio eu - é a canalização da energia militante, às vezes, longe do objetivo de eliminar o preconceito contra a homossexualidade para a construção de uma ordem burocrática às alturas da paixão cartorial nacional. Horas e horas são dedicadas à tarefa de esmiuçar a forma que o movimento deve tomar, de definir normas de comportamento nas reuniões, de controlar excessos de autoridade - acusações de "machismo" valem para este movimento o que acusações de "comunista" 
ou reacionário" valem para outros - e de criar fronteiras claras entre homossexuais e heterossexuais.

Esta importante percepção do autor cria ecos em muitos cantos. Penso, de imediato, no movimento negro no Brasil. Ele também enfrenta dificuldades em se organizar, problemas na identificação de um inimigo tangível e uma notável tendência à cisão. A República não produziu legislação explicitamente racista.

Esta constatação suscita velhos fantasmas sobre a constituição e reprodução das desigualdades sociais no Brasil, evocando inevitavelmente surrados argumentos chavões acerca da cordialidade do brasileiro. Mas representa ainda um desafio para quem quer entender uma sociedade que exibe o maior despeito pelas leis que tem - sobretudo quando os ricos as burlam - e uma estranha mas eficiente capacidade de impor leis que não têm. Senão, como explicar a perpetuação das desigualdades raciais? Como entender que as mulheres e homossexuais sentem a necessidade de pôr fim à repressão que sentem?

Estas reflexões são provavelmente parecidas com aquelas feitas pelos próprios militantes. Mas não sei se surtiram o efeito que merecem. Se o movimento negro e o movimento homossexual têm as dificuldades que têm, talvez esteja faltando um conhecimento mais apurado das formas de controle social que caracterizam a sociedade brasileira. As palavras de ordem de ambos os movimentos lembram muito as palavras de ordem dos Estados Unidos e da Europa. E, às vezes, penso que uma das razões de ser destes movimentos é a vontade de compartilhar a modernidade com os países do Primeiro Mundo, seguindo a mesma lógica das modas literárias. Mais um sinal do atrelamento cultural e econômico em geral. Certamente penso e menos cinicamente - que estas palavras de ordem carregam visões sociais que podem distorcer a visão de uma realidade social bastante diversa daquela que as produziu ou, no mínimo, criar a ilusão de que a construção social das diferenças e desigualdades não difere significativamente de um país para outro; de uma cultura para outra.

E não são apenas as formas de controle que variam.

As próprias formas de classificar o que será controlado também divergem, às vezes radicalmente. Para produzir um movimento negro, os seus militantes têm primeiro de convencer muita gente de que o 
Brasil é composto de negros e brancos e não de pretos, sararás, cafuzos, mamelucos, mulatos, etc. Da mesma forma, os militantes homossexuais tiveram que convencer o Brasil de que aqui há homossexuais, bissexuais e heterossexuais, e que esta forma de definir os personagens do cenário sexual amoroso é mais verdadeira do que aquela que tradicionalmente fala de bichas, sapatões, homens, mulheres, viados, giletes, bofes...

Ou seja, o alvo dos movimentos negros e homossexuais não é a "repressão" pura e simples, identificável e tangível; é a cultura brasileira como um todo. Não surpreende tanto, então, suas dificuldades. Por mais que se tente acreditar que transformações sociais podem ocorrer a partir das transformações individuais, o fato é que as estruturas profundas de pensamento social mudam com muito vagar. É seguramente por isso que o movimento homossexual gerou tanta frustração.

Mas, como bem aponta Edward MacRae, o movimento homossexual não foi um fracasso. Tanto assim que membros dele agora participam na luta contra os efeitos sociais mais perversos da aids. Tanto assim que o assunto da discriminação em base da orientação sexual está firmemente colocado na pauta nacional. Se não entrou nesta Constituição, entrará na próxima.

Peter Fry

Rio de Janeiro, 13 janeiro 1989 